Герман, Вікторія, і Харченко, Наталія. «Реалізація допустових семантико-синтаксичних відношень у складносурядних реченнях в наукових текстах I. Франка». Лінгвостилістичні студіï, вип. 11, 2019, c. 24-33.

Herman, Viktoriia, and Kharchenko, Nataliia. "Realization of the Concessive Semantic-syntactic Relationships in Complex Sentences (Case Study of I. Franko Scientific Works)”. Linguostylistic Studies, iss. 11, 2019, pp. 24-33.

УДК 811.161.2'367.335:821.161.2-96.09

https://doi.org/10.29038/2413-0923-2019-11-24-33

\title{
РЕАЛІЗАЦІЯ ДОПУСТОВИХ СЕМАНТИКО-СИНТАКСИЧНИХ ВІДНОШЕНЬ У СКЛАДНОСУРЯДНИХ РЕЧЕННЯХ В НАУКОВИХ ТЕКСТАХ І. ФРАНКА
}

\author{
Вікторія Герман, Наталія Харченко \\ Сумський державний педагогічний університет імені А. С. Макаренка, \\ Суми, Україна
}

У статті проаналізовано особливості синтаксичної організації функціональносемантичної категорії допустовості у складносурядному реченні 3 протиставнодопустовими й розділово-допустовими відношеннями в наукових текстах I. Франка; запропоновано значеннєве розмежування допустових відношень у складносурядному реченні відкритої та закритої структур; систематизовано засоби їх граматичної реалізації та доведено належність до периферійної зони функціонально-семантичної категорії допустовості.

Ключові слова: відкриті й закриті структури, допустовість, допустові семантико-синтаксичні відношення, протиставно-допустові відношення, розділоводопустові відношення, функціонально-семантична категорія допустовості.

\section{REALIZATION OF THE CONCESSIVE SEMANTIC-SYNTACTIC RELATIONSHIPS IN COMPLEX SENTENCES (CASE STUDY OF I. FRANKO SCIENTIFIC WORKS) Viktoriia Herman, Nataliia Kharchenko}

Sumy State Pedagogical University named after A. S. Makarenko, Sumy, Ukraine

The article is devoted to the analysis of the peculiarities of the syntactical organization of the functional-semantic category of concession in a complex sentence with opposingconcessive and separation-concessive relationships in the I. Franko scientific texts. The study has revealed a significant delineation of concessive relations in the composite sentences with open and closed structures, the means of their grammatical realization are systematized and the peripheral zone of the functional-semantic category of concession is argued in the article. The purpose of the study is to identify the peculiarities of the syntactical organization of the functional-semantic category of concession in a composite sentence with opposing-concessive and separation-concessive relations in the I. Franko scientific texts. The research methodology involved several methods: the descriptive method made it possible to define and thoroughly investigate the construction of the clauses of concession, and to systematize and clarify their semantic-syntactic structure; systematic analysis was used to identify varieties of clauses of concession. At various stages of the study, the methods of component analysis were used to study the cases of extending and reducing basic or derivative concessive constructions, and transformational analysis - in the cases of various syntactic unit

(c) Герман В., Харченко Н., Східноєвропейський національний університет імені Лесі Українки, 2019.

Це стаття відкритого доступу на умовах СC BY-NC 4.0 
transformations. The syntactic features of I. Franko's scientific texts are of great interest and require detailed scientific analysis. Analysis of the scientific papers in the field of syntax underpins the conclusion that there are only several investigations in the Ukrainian linguistics which highlight the issue of the syntaxemes with concession relationships, functioning in I. Franko's scientific texts.

Key words: open and closed structures, concession, concessive semantic-syntactic relations, adversarial-concessive relations, separation-concessivee relations, functionalsemantic concessive category.

Вступ. У сучасних лінгвістичних студіях дискусійним залишається питання про допустові семантико-синтаксичні відношення. Предметом дослідження вчених були деякі аспекти реалізації допустових відношень. Так, функціонування допустових конструкцій на матеріалі давньоруської мови окреслив Б. Лавров; інтонаційну структуру допустових речень з'ясувала I. Богданова; I. Вихованець, О. Бондарко та ін. визначили місце функціонально-семантичної категорії «допустовість» у системі мови; просте ускладнене речення 3 допустовою семантикою дослідили I. Вихованець, К. Городенська, 3. Іваненко, А. Загнітко, Т. Печонкіна, А. Прияткіна та ін. Допустові відношення вивчали переважно у зв'язку з аналізом складнопідрядного допустового речення А. Кващук, Н. Ковальова, I. Намакштанська, Т. Ткачук та ін.

Зазначені аспекти лінгвістичних студій не вичерпують проблеми вербалізації та семантики допустових речень, тож усі ці фактори умотивовують актуальність теми дослідження. I досі дискутуються проблеми, пов'язані зі статусом допустових конструкцій у системі складного й простого речень, не вповні виявлено їхні семантикосинтаксичні різновиди й не охарактеризовано засоби зв'язку; відсутня чітка структуризація категорії допустовості на функціональносемантичних засадах тощо. Важливість аналізу допустових синтаксичних одиниць зумовлена також відсутністю чіткої класифікації допустових речень, яка дозволила б установити чітку систему відношень у межах складного й простого речень. Окрім того, при аналізі наукового мовлення I. Франка зверталася увага переважно на царину лексики - фахову термінологію. Синтаксичні риси Франкових наукових текстів ще потребують докладних наукових студій. Крім того, в українському мовознавстві замало спеціальних досліджень, які б висвітлювали питання функціонування синтаксем із допустовими відношеннями в наукових текстах I. Франка.

Мета дослідження - виявити й схарактеризувати особливості синтаксичної організації функціонально-семантичної категорії допустовості у складносурядному реченні з протиставно-допустовими й розділово-допустовими відношеннями та встановити специфіку їх функціонування в наукових текстах I. Франка.

Матеріал і методи дослідження. Матеріалом для аналізу слугували літературно-критичні праці I. Франка. Дослідження складносурядних речень 
iз протиставно-допустовими й розділово-допустовими відношеннями проведено з використанням різних методів: описовий метод дав змогу виокремити й грунтовно дослідити допустові конструкції, систематизувати й з'ясувати їхню семантико-синтаксичну структуру; системний аналіз використано для кваліфікації різновидів допустових речень; на різних етапах дослідження використано також методи компонентного аналізу для згортання й розгортання базових і похідних допустових конструкцій, трансформаційного аналізу - для перетворення різних синтаксичних одиниць, що уможливило диференціацію базових і похідних конструкцій.

Результати дослідження та дискусія. Проблема допустових семантико-синтаксичних відношень у складносурядному реченні залишається актуальною, хоча принагідно знаходимо в лінгвістичних працях окремі зауваження про спроможність складносурядного речення передавати семантику допустовості (Белошапкова; Вихованець; Грищенко; Каранська). Так, А. Васильєва зосередила увагу на аналізі основних видів допустових семантико-синтаксичних відношень, що формуються всередині складносурядного речення, на матеріалі німецької мови (21-2), однак розглянула тільки конструкції 3 допустово-протиставними відношеннями, утвореними за зразком хоч... але. На наш погляд, найбільш грунтовно це питання висвітлила М. Ляпон у праці «Смысловая структура сложного предложения и текст. К типологии внутритекстовых отношений». Дослідниця простежила можливість взаємозаміни допустових і протиставних сполучних засобів, роль мікроконтексту при цьому, а також межі поширення допустових відношень у складносурядному реченні (Ляпон 152-67).

$€$ підстави вважати, що зближення функціонально-семантичної категорії (ФСК) допустовості й протиставності зумовлює появу проміжних семантико-синтаксичних відношень, які виникають на основі складнопідрядних і складносурядних речень. Саме тому деякі мовознавці розглядають допустові семантико-синтаксичні відношення в межах сурядних протиставних (Буслаєв 338), а інші - констатують наявність протиставно-допустових значень у складнопідрядному реченні (Грищенко 91; Загнітко, Сучасна 52).

у пропонованій розвідці ФСК допустовості кваліфікуємо як комплекс мовних засобів, які застосовуються в оформленні модальної семантики подоланої суперечності, що відображає в реченні (складному або простому ускладненому) зумовлене об'єктивною дійсністю й законами мислення значення, передане за допомогою семантико-синтаксичних мовних засобів. Допустовість трактуємо як семантико-синтаксичну категорію, яка відтворює логічні відношення зворотної зумовленості між реальною чи уявною дійсністю або за двома ознаками, діями, станами однієї дійсності. Допустові семантико-синтаксичні відношення кваліфікуємо як такі, в яких одна предикативна частина виражає несприятливу підставу 
чи умову, незважаючи на яку або всупереч якій відбувається дія в іншій частині речення.

Беззаперечно, що особливістю допустової семантики є поєднання, 3 одного боку, умовних, причинових і наслідкових відношень, а з іншого обмежувальних і протиставних, зрідка - розділових. Іноді певні відношення переважають, стають домінантними, а інші виявляються імпліцитно. Тому проблемним, на нашу думку, $\epsilon$ не лише визначення меж так званих «чистих» допустових відношень, але й мішаних, синкретичних.

Вважаємо, що допустові семантико-синтаксичні відношення взагалі й у науковій мові І. Франка зокрема реалізуються в складнопідрядному реченні з різновидами власне-допустового й невласне-допустового значення (допустово-протиставного, допустово-умовного); у складносурядному протиставно-допустового й розділово-допустового значення; у простому ускладненому - допустово-протиставного, допустово-умовного й розділоводопустового значення. Зосередимося на особливостях вербалізації допустових семантико-синтаксичних відношень у складносурядних реченнях, виокремлених у наукових творах I. Франка.

Більшість лінгвістів складносурядні речення диференціюють на два типи за структурою - відкритої (ряди їхніх частин $є$ незамкненими, можуть мати будь-яку кількість структурних частин) і закритої (наявні лише дві структурні частини) структури (Вихованець 306-307; Загнітко, Сучасні 49). Кожен зі структурних типів має свої характерні сполучні засоби: предикативні частини речень відкритої структури поєднуються єднальними й розділовими сполучниками, закритої - зіставними, протиставними, приєднувальними й градаційними (Вихованець 307).

Дослідження проблематики показало, що існує два підходи до кваліфікації семантико-синтаксичних відношень, які передають складносурядні речення відкритої структури. Так, І. Слинько розглядає такі відношення як розділово-допустові (567), а М. Ляпон їх кваліфікує як альтернативно-протиставні (147-8). Тому до кінця не з'ясовано статус таких складних речень: одні мовознавці розглядають їх серед складнопідрядних, інші - серед складносурядних, треті - як конструкції, що поєднують ознаки складносурядного та складнопідрядного речень. Пропонуємо розглядати їх як складносурядні й спробуємо довести, що допустові семантико-синтаксичні відношення реалізуються у відкритих і закритих складносурядних структурах.

Керуючись таким підходом, констатуємо, що за структурою, семантично й сполучними засобами (другий компонент парного сполучника у складнопідрядному реченні - це протиставний сполучник) складнопідрядні допустові речення (далі СПР), вживані I. Франком, дуже близькі до складносурядних речень (далі ССР) закритої структури, пор.: Хоч mi дальші роки його життя заповнені працею журналістичною та науковою, а всетаки на них тяжить якась важка хмара... (Франко 112) (СПР) - Глибока релігійність, у порівнянню зі Словацьким, могла в щасливіших обставинах 
допомогти йому до створення далеко більшого числа безсмертних творів, $\boldsymbol{a}$ все-таки незавидні обставини його пізнішого життя підкопали та виссали передчасом його творчу силу і завели його на дорогу, що не могла обіцяти ніяких тривких успіхів (Франко 111) (ССР); Тим вищої похвали заслуговує саме виконання, нехай яке $i$ не дорівнює оригіналу сміливістю $i$ лапідарністю стилю, але простими словами в мелодійному і звучному вірші воно вірно передає думки оригіналу (Франко 116) (СПР) - Головне поле боротьби, головна мета перемог та завоювань із сфери крові та плоті перенеслася вже в сферу духа та слова, але старі вороги людського роду, деспотизм та темнота, ще аж занадто сильні реальною могутністю, занадто гордо іноді ще підносять чоло, аби мечі могли зовсім уже піти між старе заліззя або на перекування (Франко 120) (ССР); Нехай Словацький перестав бути польською суспільно-політичною євангелією, та не перестав він бути незрівнянним майстром польського слова, майстром поетичної форми та улюбленим поетом молоді, володарем їі мрій $i$ почуттів (Франко 134) (СПР) - Аналіз самого цього твору з літературного погляду відійшов тут дещо на задній план, та дуже цікаві досліди над історичним тлом поеми "Jana Bieleckiego» (Франко 138) (ССР).

Погоджуємося з гіпотезою мовознавців, які стверджують, що іншою важливою ознакою, яка дає підстави констатувати подібність підрядних і сурядних протиставних відношень, $\epsilon$ фіксований порядок частин у складносурядному реченні 3 протиставними семантико-синтаксичними відношеннями, а саме: під час протиставлення й зіставлення присудків протиставлюване або зіставлюване слово вживається, як правило, на початку другої частини. У складносурядних реченнях зі значенням послідовного розгортання подій у часі, наслідковості, протиставлення послідовність їхніх частин зумовлена логічно; у будові таких складних речень немає жодних формальних показників синтаксичної залежності однієї частини від іншої, отже, вони синтаксично рівноправні.

Але є підстави вважати, що відтінок підрядності або взаємопідрядності виникає за умови, якщо в структурі таких речень з'являються формальні ознаки синтаксичної взаємозумовленості, наприклад, у І. Франка: Мати й не хотіла видати сина, але король таки довідався про все через підслух (Франко 311); Се була правда, але ніхто не хотів сьому вірити (Франко 311). Отже, фіксований порядок частин у складносурядному протиставному реченні - це ще одна характерна особливість, що наближає такі речення до складнопідрядних допустових.

На думку М. Ляпон, якщо протиставлення є невід'ємним складником семантики допустовості, то і сполучні засоби, які використовують для вираження допустових семантико-синтаксичних відношень, можуть бути замінені протиставними переважно тоді, коли ці відношення $є$ допустовопротиставними, і навпаки, протиставні сполучники можна замінити допустовими (Ляпон 152). 
Результати синтаксичного аналізу наукових творів I. Франка переконують, що предикативні частини складносурядних речень із протиставно-допустовими відношеннями дій, процесів або станів найчастіше поєднуються сполучниками $a$, але, зате, проте, однак/одначе, ma (у значенні але). Погоджуємося з І. Вихованцем і А. Загнітком у тому, що ці сполучники також можуть семантично диференціювати протиставнодопустові семантико-синтаксичні відношення, причому межа між протиставно-допустовими й протиставними семантико-синтаксичними відношеннями $\epsilon$ дуже розмитою, оскільки часто речення із власнепротиставними відношеннями можна трансформувати в речення із протиставно-допустовими відношеннями (Вихованець 308; Загнітко, Сучасна 52). Вважаємо, що ця подібність пояснюється такими факторами: ситуація протиставлення подій, фактів, явищ тощо у підрядних частинах; обидва типи - речення закритої структури; використовуються однакові засоби зв'язку; тотожною $є$ фіксована послідовність предикативних частин, згідно з якою спочатку - твердження, а потім - заперечення, обмеження цього твердження.

Виокремлюючи конструкції з протиставно-допустовими семантикосинтаксичними відношення в науковій мові І. Франка, ми послуговувалися порадою А. Грищенка: потрібно зважати на сукупність засобів вираження цих відношень, зокрема на лексичне наповнення компонентів та характер зв'язку між ними, оскільки в складносурядному реченні визначальними $\epsilon$ не сполучні засоби, а семантико-синтаксичні відношення (98). Відтак вважаємо, що серед виокремлених лінгвістом протиставних конструкцій (протиставно-зіставні, протиставно-видільні, альтернативно-протиставні, протиставно-наслідкові, протиставно-мотиваційні, протиставноприєднувальні) (Грищенко 71) найтісніше з допустово-протиставними пов'язані протиставно-обмежувальні (у них зміст другої частини перешкоджає реалізації того, про що говориться в першій; вживаються сполучники але, та, проте, однак) і речення зі значенням невідповідності (друга частина протиставляється першій як таке, що суперечить їй). Результати дослідження підтверджують, що нашарування допустової семантики виникає переважно тоді, коли йдеться про контрастне протиставлення двох дій, фактів, станів, одна (один) з яких заперечує або обмежує наявність, здійснення іншої (іншого).

Основною умовою виокремлення допустових семантико-синтаксичних відношень у складносурядному реченні $\epsilon$ розподіл функціональних ролей між частинами цього речення: протиставний сполучник повинен поєднувати сурядні частини, перша з яких виконує функцію потенційної причини, а наступна може спростовувати, заперечувати попередню, водночас виразною має бути семантика «всупереч очікуваному» (Ткачук 78): Взята фігура шотландського патріота Ленокса з іншого уступу Голіншедової хроніки навіть не була сучасною Макбетові, але була вона виведена Шекспіром у драмі як протопласт Дарнлея, батька короля 
Джемса, а мужа Марії Стюарт (Франко 327); Шотландиі у війні були побиті - рівночасно Макбет на однім крилі, а Банко на другім, але потім, участувавши норвежців вином, приправленим сон-зіллям, шотландці вимордували їх (Франко 329-30); Деякі риси для малюнка сеї фігури взяв Шекспір із інших місць Голіншедової хроніки, то проте ся фігура в свойому цілому - власний додаток Шекспіра до Макбетової трагедії (Франко 330).

На думку I. Вихованця, згідно 3 семантичним показником, найвіддаленішим від контрастного плану $є$ складносурядне речення, в якому сурядні частини поєднані сполучником зате, що виражає протиставно-компенсувальне значення (311). Переконуємося в цьому на таких прикладах: Англія привертає в Шотландії легального короля, зате по пророцтву вона має й сама з шотландського роду одержати королівську династію (Франко 324); Ради Волюмнії синові не можна вважати знаком високої моральності, зате, безперечно, вони належать до катехізму аристократичної політики (Франко 340).

Знаходимо нечастотні випадки вживання I. Франком діалектного сполучника прецінь, синонімічного до протиставних проте, однак/одначе: Шекспір не знав геніальної «Медеї» Евріпіда, то прецінь без найменшого сумніву він знав латинську «Медею» Сенеки, розводнену, риторичну копію грецької (Франко 330); В усякім разі «Приборкана гоструха» $i$ «Венецький купець» були написані коло 1596 р., прецінь «Приборкана гоструха» була видана аж по смерті автора, в виданню in folio 1623 (Франко 341).

Переконуємося, що допустове значення в складносурядному протиставному реченні граматично не виражене, тому основне навантаження в таких реченнях припадає на лексичне значення компонентів сурядних частин, а також на допоміжні засоби, які, увиразнюючи заперечностверджувальне протиставлення, перебирають на себе функцію допустових сполучників (Ткачук 79). Це переважно частки-актуалізатори все (усе)-таки, все (усе) ж, все (усе) ж таки, i, все (усе) одно, вже (уже), наприклад: Правда,1584 р. Реджінальд Скотт у книжці «The discovery of witchcraft» («Відкриття чарівництва») основно і дуже розумно виказав усю глупоту віри в чарівництво, але його голос усе одно пролунав без відгуку (Франко 331); На основі зовсім недостаточних доказів його засуджено на смерть, але все ж таки вироку не виконано (Франко 335).

Труднощі у з'ясуванні належності розділово-допустових семантикосинтаксичних відношень до сурядності чи підрядності пов'язана передусім із синкретичним характером цих відношень. Для таких речень характерними є такі ознаки: вживаються повторювані розділові сполучники; наявна ще й третя предикативна частина зі значенням, характерним для головної частини складнопідрядного речення з допустовим семантикосинтаксичним відношенням; семантика узагальненості; значення протиставлення. Такі ознаки дають підстави розглядати складносурядні речення з розділово-допустовими семантико-синтаксичними відношеннями 
в периферійній зоні складнопідрядного речення 3 узагальненодопустовою частиною.

У структурі складносурядного речення 3 розділово-допустовими відношеннями виокремлюємо щонайменше три компоненти: основний, у якому висувають припущення або щось стверджують, та два залежні, які вступають між собою в розділові семантико-синтаксичні відношення, водночас кожен із них, усуваючи іншого, спростовує, заперечує висловлену думку в основному компоненті (Ткачук 81). Тричленна структура зумовлює переважно трикомпонентність сполучних засобів: залежні частини пов'язані повторюваними розділовими сполучниками хоч... хоч..., чи... чи..., а в головній частині вживаються протиставні сполучники $a$, зрідка але, так, що разом утворюють аналітичні сполучникові комплекси хоч... хоч... а, хоч... хоч... але, хоч... хоч... так; чи... чи... $а$, чи... чи... але, чи... чи... так. Наприклад: Хоча автор зумів підняти фігури Катерини і Петручія на вищий цивілізаційний ступінь, хоча вони осяяні блиском Шекспірового генія, але вони не переведені ним зовсім консеквентно, не продумані так глибоко (Франко 345); Хоч з морального боку німцям не можна зробити ніякого закиду, хоч їхня солідарність, наполегливість $i$ організованість викликають у нас подив, а все ж таки, співчуваючи усім серцем темному, слабому, доброму, як дитина, польському селянинові... (Франко 91); Чи оповідають ті твори про факти далекі та виїмкові, чи малюють людей видуманих і незвичайних, проте раз у раз хапають нас за душу, ворушать в ній найглибші чуття, здобувають собі наше неослабне вподобання (Франко 466).

Основна форма парадигми таких речень у мовотворчості I. Франка, як переконують досліджені матеріали, - зі сполучником хоч... хоч...: Хоч Ізабелла - се просте, різке, противенство Дездемони, хоч вона приймає провід низького брехунця, розпусника та циніка Люція, «небезпечного приятеля», але брудна хвиля людського кривосуддя, людського горя й зіпсуття не доторкається ї̈ ніже крапелиною (Франко 400). Сполучник чи... чи... надає реченням відтінку непевності у ставленні мовця до розділюваних ним думок, він має стилістичний варіант - сполучник що... що...: Чи далекі за своїм сюжетом від сучасного життя, чи змішуються вони з розбурханим, каламутним потоком дійсного політичного життя Німеччини, але драми Шіллера сталися огнистою проповіддю думок великої французької революції, сталися самі революцією в Німеччині (Франко 411); Що на той час на німецьких землях посилився крайній політичний упадок, що продовжувалося там добровільне пониження найвищих вершків суспільності, $\boldsymbol{a}$ зовсім відмінний образ бачимо в середніх верствах (Франко 409).

У науковій мові I. Франка вживаються розділово-допустові складносурядні речення, в яких пропущено протиставний сполучник. У таких конструкціях використовуються лише повторювані розділові сполучники хоч... хоч..., чи... чи..., а основна частина приєднується до залежних лише за допомогою інтонації (Ткачук 83). Вважаємо, що протиставлення в таких реченнях виражається яскраво, що на письмі 
передається вживанням тире: Дарма хоч не високої стійності Брукова поема, хоч більш примітивна вона, ніж Банделлеве джерело, - вона свідчить про деякий талант (Франко 359); Хоч в старшій драмі про Ліра є також ніч з громами й бурею, хоч $є$ також Лір, вигнаний дочками на пустелю, там він не божеволіє, лише кається (Франко 389); Чи його власне я в тій страшній катастрофі щезає перед його свідомістю, чи він чує себе лише частиною загальної нужди, загального горя всіх бідних та покривджених, Шекспірів Лір не знає покаяння, не згадує про Корделю (Франко 389).

Аналіз складного речення як фрагмента синтаксичної структури наукових текстів I. Франка дав змогу виявити працю письменника над удосконаленням синтаксичної організації його творів. Так, у межах речення з допустовими відношеннями I. Франко послідовно замінював сполучники хоть (хотя) - на хоч (хоча). Ці авторські виправлення свідчать про прагнення письменника удосконалити синтаксичну структуру наукових текстів.

Наукові й науково-популярні праці I. Франка заклали міцний фундамент у формування наукового стилю української літературної мови, в удосконалення його синтаксичної організації. Висока частота вживання I. Франком поліпредикативних синтаксичних конструкцій із допустовими семантико-синтаксичними відношеннями зумовлена потребою максимально точно відтворити багатоманітні логічні й змістові відношення між частинами висловлювання.

Висновки та перспективи досліджень. Проведений аналіз синтаксичної організації речень I. Франка доводить, що допустові семантико-синтаксичні відношення реалізуються, крім складнопідрядних, і в складносурядних конструкціях. У складносурядних реченнях фіксуємо протиставно-допустову й розділово-допустову семантики. Протиставнодопустова семантика в закритих структурах вербалізується лексичним значенням предикативних компонентів. Основним показником таких відношень $\epsilon$ взаємодія предикативних частин, в одній з яких висловлене твердження або припущення 3 можливим наслідком, а в іншій це спростовується, обмежується чи заперечується. Важливу роль у таких реченнях відіграють частки-актуалізатори. Такі речення належать до периферійної зони ФСК допустовості. Значення протиставлення зближує розділово-допустові складносурядні речення з протиставно-допустовими. Складні речення 3 розділово-допустовими відношеннями, вживані I. Франком, більше тяжіють до складносурядних, бо дві їхні частини поєднані між собою повторюваними розділовими сполучниками хоч... хоч..., чи... чи..., а третя приєднується протиставними сполучниками $a$, aлe. Саме наявність третьої частини зі значенням, характерним для головної частини складнопідрядного допустового речення, а також вираження семантики узагальненості, дає підстави розглядати такі складносурядні речення в периферійній зоні ФСК допустовості. Перспективним вважаємо аналіз синтаксичної організації функціонально-семантичної категорії допустовості на функціонально-семантичних засадах у простому ускладненому реченні в наукових текстах I. Франка. 


\section{Список використаної літератури}

Белошапкова, Вера. Современный русский язык. Москва: Высшая школа, 1977.

Буслаев, Федор. Историческая грамматика русского языка. Синтаксис. Москва: Изд-во Братьев Соколовых, 1875.

Васильева, Анна. Синтаксические способы выражения уступительности в немецком языке. Автореф. дисс. ... канд. филол. наук. Ленинград, 1965.

Вихованець, Іван. Граматика української мови. Синтаксис. Київ: Либідь, 1993.

Грищенко, Арнольд. Складносурядне речення в сучасній українській літературній мові. Київ: Наукова думка, 1969.

Загнітко, Анатолій. Сучасна украӥнська літературна мова. Синтаксис простого ускладненого і складного речення. Донецьк, 1994.

Загнітко, Анатолій. Теорія сучасного синтаксису. Донецьк, 2006.

Каранська, Марія. Синтаксис української літературної мови. Київ: Либідь, 1995.

Ковальова, Наталя. Структурні, логіко-семантичні і функціональні типи допустових речень у сучасній українській науковій мові. Автореф. дис. ... канд. філол. наук: 10.02.01. Дніпропетровськ, 2005.

Ляпон, Майя. Смысловая структура сложного предложения и текст. К типологии внутритекстовых отношений. Москва: Наука, 1986.

Мусатова, Г. «Функционально-семантическое поле уступительности и его структура». Филология и лингвистика в современном обществе. Москва: Буки-Веди, 2014, c. 95-100.

Слинько, Іларіон, Гуйванюк, Ніна, і Кобилянська, Марія. Синтаксис сучасної української мови. Проблемні питання. Київ: Вища школа, 1994.

Ткачук, Тарас. Функціонально-семантична категорія допустовості в сучасній українській мові. Дис. ... канд. філол. наук: спец. 10.02.01. Київ, 2009.

Франко, Іван. Твори. В 20 т. Т. 18. Київ, 1955.

\section{References}

Beloshapkova, Vera. Sovremennyj russkij jazyk. Moskva: Vysshaja shkola, 1977.

Buslaev, Fedor. Istoricheskaja grammatika russkogo jazyka. Sintaksis. Moskva: Izd-vo Brat'ev Sokolovyh, 1875.

Vasil'eva, Anna. Sintaksicheskie sposoby vyrazhenija ustupitel'nosti v nemeckom jazyke. PhD Thesis Abstract. Leningrad, 1965.

Vykhovanets, Ivan. Hramatyka ukrainskoi movy. Syntaksys. Kyiv: Lybid, 1993.

Hryshchenko, Arnold. Skladnosuriadne rechennia v suchasnii ukrainskii literaturnii movi. Kyiv: Naukova dumka, 1969.

Zahnitko, Anatolii. Suchasna ukrainska literaturna mova. Syntaksys prostoho uskladnenoho $i$ skladnoho rechennia. Donetsk, 1994.

Zahnitko, Anatolii. Teoriia suchasnoho syntaksysu. Donetsk, 2006.

Karanska, Mariia. Syntaksys ukrainskoi literaturnoi movy. Kyiv: Lybid, 1995.

Kovalova, Natalia. Strukturni, lohiko-semantychni i funktsionalni typy dopustovykh rechen $u$ suchasnii ukrainskii naukovii movi. PhD Thesis Abstract. Dnipropetrovsk, 2005.

Ljapon, Majja. Smyslovaja struktura slozhnogo predlozhenija i tekst. K tipologii vnutritekstovyh otnoshenij. Moskva: Nauka, 1986.

Musatova, G. "Funkcional'no-semanticheskoe pole ustupitel'nosti i ego struktura". Filologija $i$ lingvistika v sovremennom obshhestve. Moskva: Buki-Vedi, 2014, pp. 95-100.

Slynko, Ilarion, Huivaniuk, Nina, and Kobylianska, Mariia. Syntaksys suchasnoi ukrainskoi movy. Problemni pytannia. Kyiv: Vyshcha shkola, 1994.

Tkachuk, Taras. Functional-semantic category of concessiveness in the modern Ukrainian language. PhD Thesis. Kyiv, 2009.

Franko, Ivan. Tvory. 20 vols. Vol. 18. Kyiv, 1955. 